\title{
JEMAAH ISLAMIYAH \\ JIHADIST MOVEMENT IN INDONESIA
}

\author{
Raden Cecep Lukman Yasin \\ Fakultas Syariah, Universitas Islam Negeri (UIN) Malang \\ Jl. Gajayana 50 Malang 65144 Telp. 0341-551354, 558882 \\ Faks. 0341-572533, 0341-558882
}

\section{Abstrak}

Keran demokrasi yang terbuka lebar pasca-kejatuhan rejim Soeharto telah menciptakan euphoria dalam ruang kehidupan publik. Berbagai aktifitas sosial politik yang sebelumnya dibungkam dan disisihkan, kini mulai memadati ruang publik. Kemunculan kelompok radikal Islam yang telah banyak menyedot perhatian publik dengan aksi-aksi mereka yang bernuasa terror, psikologis maupun fisik, tidak bisa dilepaskan dari keterbukaan ini. Di antara kelompok yang dipandang sebagai garda depan gerakan radikal ini adalah Jemaah Islamiyah. Tulisan berikut berusaha menelurusi akar kemunculan gerakan tersebut dan perkembangannya sepanjang dua dekade terakhir, berikut perpecahan internal dan metamorphosis gerakan bawah tanah itu menjadi gerakan terbuka. Sementara banyak kalangan mengaitkan gerakan tersebut dengan pengaruh islamisme yang kuat dari Timur Tengah, tulisan ini menyodorkan argumentasi bahwa pandangan di atas jelas telah mengabaikan sejarah gerakan radikal Islam dalam lanskap sosial politik Indonesia. Kajian yang cermat terhadap Jemaah Islamiyah menunjukkan bahwa gerakan tersebut memiliki karakteristik lokal yang kental.

Kata kunci: gerakan, radikal

\section{Introduction}

Violence perpetrated by Muslim radicals is not a new phenomenon in Indonesia and was common from time to time during Soehartos authoritarian regime (1966-1998). In fact it is often argued that the Soeharto regimes severe repression of political Islam contributed to the radicalization of Muslim dissents. While the Muslim mainstream has welcomed the democratization of Indonesia since Soehartos fall in 1998, a small radical 
fringe has resorted to intimidation and violence. Proponents of radical Islam remain a small minority, and most of them are devout practitioners who would never dream of using violence. However, even a tiny group of people can cause an immense amount of damage; foremost among them is Jemaah Islamiyah (JI).

This present study tries to explore the development of JI from its origin in 1993 to its involvement in violent jihad throughout Indonesia. It also assesses the impact of Islamist ideas on JI and its evolution from a secretive organization into an open one. While many believe that the rise of terror in Indonesia is the proof of the malignant effect of Middle Eastern Islamism on the region, this study will argue that such a view ignores Indonesia s history of violent Muslim extremism. The study will examine that JI is the product of a complex interaction of local and external factors. In the final analysis, the study will examine whether or not the JI will succeed in its effort to establish a unified South-East Asian Islamic state, encom-passing Indonesia, Malaysia, Singapore, the southern Philippines and southern Thailand.

\section{The Origin and Development of Jemaah Islamiyah}

JI has its origins in the Darul Islam (DI) separatist movement in Indonesia. DI was involved in regional rebellions in the 1950 s and $1960 \mathrm{~s}$ that sought to impose Islamic law or form Islamic states in parts of Indonesia: The movement was strongest in West Java, South Sumatra and South Sulawesi, areas where JI is most heavily represented today. Under their own independent leaders, the name Darul Islam was used by these three separatist movements. Darul Islam in West Java was under the leadership of Soekarmadji Maridjan Kartosoewirjo, in South Sulawesi under Kahar Muzakkar, and in Aceh under Daud Beureueh. In 1953, all of them agreed to form a unified front to establish the Islamic State of Indonesia, and S.M. Kartosoewirjo become the first imam of the state (Jones, 2005b: 2). After DI insurgency was suppressed by Soekarno regime in the mid-1960s, it continued to exist as a clandestine political movement working for imposing Islamic law in Indonesia. JI evolved as a secretive militant organization from a faction of DI, led by Abdullah Sungkar. After being crushed in mid 
1960s, Darul Islam operated underground, under the leadership of Ajengan Masduki. His split with Sungkar led to Sungkar s forming of JI. Together with his long-time associate, Abu Bakar Baasyir, in 1971 Sungkar established an Islamic boarding school al-Mukmin at Ngruki, Central Java. Sungkar and Baasyir are both of Yemen descent. They were born a year apart, Sungkar in 1937 in Solo, Central Java, and Baasyir a year later in Jombang, East Java. Born in Indonesia, they both speak Bahasa Indonesia fluently. Being Yemen descent gives them no privilege within Indonesian Muslim community. Their followers were attracted to their cause, not so much to their family background, as to their eloquent oratory. Both became leaders of Gerakan Pemuda Islam Indonesia (Indonesian Muslim Youth Movement, GPII), an independent and activist student group that had close ties to the Masjumi, the main modernist Islamic political party that was banned in 1960. Both were also deeply involved in dakwah (proselytisation) activities and in 1967 found a radio station called Radio Dakwah Islamiyah Surakarta. In 1975 the radio station was shut down by the Suharto regime for its political content and anti-government tone. (Jones, 2002: 6). In 1978, Sungkar and Baasyir were arrested by Soeharto regime for violating a 1963 subversion law, and imprisoned for four years. The imprisonment was due to their speeches that attack the regime and their demand to implement Shariah. Sidney Jones noted that the governments case against the two men rests far more on the content of statements urging disobedience to secular authority than on any evidence of an underground organization. (Jones, 2002: 7). In 1985 they fled to Malaysia to escape a crackdown by Indonesian authorities on Muslim militants. Malaysia became a safe haven for them, where they lived and preached openly and built up a large following of radical Indonesians who also fled the Soeharto regime. These Indonesian exiles developed links with the Muslim separatist movement in the southern Philippines, Moro Islamic Liberation Front (MILF), including running joint operations and training camps with Kumpulan Mujahidin Malaysia (Malaysian Mujahidin Group, KMM).

It was during the exile in Malaysia that Sungkar officially founded Jemaah Islamiyah in January 1993. Like al-Qaeda, it is a genuine transnational movement whose aim is to create an Islamic caliphate of South- 
East Asia, within which Shariah would be implemented. Inspired by alIkhwan al-Muslimun of Egypt, he asserted that the struggle for an Islamic state is a step-by-step process starting with the moral self-improvement of the members until they are able to form a family (usrah) of like-minded people. These are the crucial steps toward the building of an Islamic community (jemaah Islamiyah), which is a precondition for the establishment of an Islamic state (van Bruinessen, 2002: 7). However, recruiting potential members of JI is a slow process, developing over time as the recruiters slowly assessed the dedication of the recruit. The recruitment process occurred in phases. The first phase involved screening individuals, including their family. background and knowledge of Islam. Once the recruits are selected, they will be enrolled at boarding schools and madrasahs for further training. The next phase is a physical and military training in either al-Qaeda camps in Afghanistan or in MILF camp of Hudaibiyah in Mindanao, Philippines. While the recruits belong to various social levels, they have the commonality of being angry with what is happening to Muslims (Abuza, 2003: 131).

\section{Actions and Network of Jemaah Islamiyah}

During the period of early 1980s to the mid 1990s, JI has sent more than 300 Indonesians to foreign mujahidin camps, especially to Afghanistan where they got military training under Abdul Rasul Sayyaf, the Afghan commander who had the closest ties to Saudi Arabia and Osama bin Laden. It is important to note in this regard that JI did not exist as an organization when Sungkar started to send Indonesian fighters to Afghanistan. A small number of them were trained at the camps of other Afghan leaders such as Gulbuddin Hekmatyar and Jamil al-Rahman. It was in Afghanistan that JI members learnt the skills necessary for their military actions, such as bomb making, use of armaments, and covert operation technique. Using the skills gained in the crucible of the war in Afghanistan, JI developed a.formalized structure to provide systematic training for its new recruits from across the region. In May 1996, Sungkar and some of the Afghan veterans con-solidated the structure of JI regional operations similar to a military structure, and documented it in a book often referred to as Pedoman Perjuangan alJamaah al-Islamiyah (General Guideline for the Jemaah Islamiyah Struggle, 
PUPJI). According to PUPJI, JIs regional operations are divided into three main Mantiqis (Region or Brigade). Each Mantiqi is broken down into Wakalah (battalion), Khatibah (company), Qirdas (platoon), and Fiah (squad). Each Mantiqi is assigned to operation in certain areas. Mantiqi I covers peninsular Malaysia and Singapore; Mantiqi II covers Java, Sumatra and most of eastern Indonesia; Mantiqi III covers Sabah, East Kalimantan, Sulawesi and Mindanao; Mantiqi IV, which has never been realized, has been generally described as covering Papua and Australia. (Abas, 2003: 108). Apart from military training, Indonesian mujahidin were also provided with religious and ideological indoctrination. As with many of the Saudi funded camps, there was a heavy focus on salafi teaching, though of a jihadist bent. The term salafi is used to describe a movement that seeks to return to the purity of the religion as practiced by the Prophet and the two generation following him. Salafi movement is characterized by the emphasis on purifying Islam from deviations such as idolatry (shirk), unwar-ranted innovation (bidah) and superstition (khurafat). However, contem-porary salafi movement is a form of reconstituted Wahhabism, owing to the determination of its proponents to more systematically introduce the thought formulated by the three main classical references among Wahhabis, namely Ahmad ibn Taymiyyah (1263-1328), Muhammad ibn Qayyim al-Jawjiyyah (12921350) and Muhammad ibn Abd al-Wahhab (1703-1792). Also taught in the camp is Abdullah Azzams ideas, which echoes Ibn Taymiyahs arguments that jihad means armed struggle and that it was legitimate to wage jihad against Muslim rulers who deviate from true Islam or refuse to enforce shariah. Ibn Taymiyah was an important fourteenth century theologian. He cultivated the idea that Muslim rulers who con-travened Islam should be labeled kuffar (unbelievers), and it is incumbent upon Muslims to wage jihad to overthrow kuffar rulers. This idea resonates with that of Darul Islam movement whose struggle to uphold shariah, let alone establish an Islamic state, were repressed by Soeharto regime (Jones, 2003: 3). This indoctrination of jihadist idea provides JI members a powerful religious sanction for the use of violence to gain their goal. JIs members were taught about the need to wage jihad as a way of becoming a good Muslim. The book used in jihad training talks about the necessity of using violence in 
order to achieve peace. The book teaches that if the enemies are trying to destroy the religion and the Muslim community, the only way toward living life according to Islamic principles is to use violence to fight them, and if the only means of disposal are bombs, sabotage and other tactics of war, so be it (http://abc.net.au/4corners/content/2003/20031103_still_at large/ int jones.htm).

A number of international terrorist experts came to engage in discussing the linkage between JI and al-Qaeda. Rohan Gunaratna, for instance, alleged a link by presenting evidence of al-Qaeda involvement in terrorist acts in Indonesia (Gunaratna, 2002: 264-270). Sidney Jones issued a report highlighting the linkage and cited the Ngruki pesantren (Islamic boarding school) as the hub of the JI network. In this report, JI is defined as a clandestine regional al-Qaeda-linked terrorist organization whose network of supporters is scattered across Southeast Asian countries and includes KMM (Jones, 2005: 1). Even though there are close and direct links, JI and al-Qaeda operate largely independently of each other. The relation between the organizations is more a loose alliance forged through a shared ideology, rather than a hierarchical structure of command and control. In an interview with Abuza, Baasyir denied being a member of al-Qaeda, but confessed that he respects the struggle of Osama bin Laden whom he considered as representing Muslim world against the United States and their allies (Abuza, 2003: 161). However, al-Qaeda is a potent inspiration and example to South-East Asian Muslim militants, and has provided resources for their military operation. Al-Chaidar, one of the leaders of Darul Islam factions, has admitted to receive funding and assis-tance from alQaeda due to Darul Islams special relationship with Osama bin Laden. According to Al-Chaidar, wherever jihad is conducted, al-Qaeda network will provide money and weapons, and mobilize fighters to go to the jihad front (Abuza, 2003: 145 and 148). Ideologically, the Middle Eastern and Arab influence on JI is also unmistakable, especially from the ideas of Sayyid Qutb, an ideologue of the Ikhwan al-Muslimun. An ideological heir of Hasan al-Banna, Qutb expanded and refined the aims of the Muslim Brotherhood. Alongside the slogan "Islam is the solution," his concept of jahiliyah (ignorance) gained wide currency among Islamists. This concept 
describes the situation of the Muslim world under the secular nationalist regimes as being in a state of ignorance and barbarism, and this undoubtedly provoked the consciousness of Islamists to resist the established order and devise actions that were aimed to overturn and transform it (Ayubi, 1991: 131). Therefore it is scarcely surprising to say that JI is a product of international jihadist forces given the back-ground of many of its leaders, its ideological orientation, and its well esta-blished links with foreign militant Muslim networks, most notably that of al-Qaeda. This network would later prove critical to JIs ability to mount large, well-coordinated operations. The Christmas Eve bombing of December 2000 is often cited as an example of the well-organized attack and professionalism of JI field operatives. The coordination in the bombings was impressive in which the explosions went off at around the same time in over 30 churches in 11 cities throughout Indonesia (Jones, 2005a: 5).

Following the fall of Soeharto regime in 1998, hundreds of radical Muslim exiles, mostly from Malaysia and Philippines, returned home and demanded political space. Sungkar and Baasyir threw themselves into the new political environment, feverishly working to build up followers committed to turning the post-Soeharto government into an Islamic state. After the natural death of Sungkar in 1999, Baasyir took over leadership of the organization. It was at this point that the division within JI began to appear because many of the younger and more radical members of JI were unhappy with the leadership of Baasyir. The division within the organization widened when Baasyir accepted the leadership of Majlis Mujahidin Indonesia (MMI, Indonesian Mujahidin Council) in August 2000. PostSoeharto Indonesia heralded a new openness for Islamic organization within the country. Baasyir felt that the time was right to take advantage of the new political climate. MMI is ostensibly a civil society organization that tries to implement shariah peacefully and through the democratic process (Abuza, 2003: 141-142). MII headquarter locates at Karanglo Street no. 123, Yogyakarta, Central Java. It serves as an umbrella organi-zation and coordinating body for many militant and hard-line Islamic organizations and groups that are committed to the establishment of an Islamic state, such as Laskar Jihad (Holy War Force), Front Pembela Islam (Front of 
Defenders of Islam), Laskar Jundullah (Gods Army Paramilitary), Brigade Taliban (Taliban Brigade). These Muslim militant groups operate openly and achieved notoriety by taking to the streets to demand the comprehensive implementation of shariah, raiding cafes, discotheques, casinos, brothels and other reputed dens of iniquity, and most importantly, calling for jihad in Moluccas and other trouble spots in Indonesia. MMI has a broad membership, including prominent figures of Indonesian Muslim scholars and politicians who seek to bring about an Islamic state through peaceful and democratic means, such as Deliar Noer, Ali Yafie and A.M. Saefuddin. They are appointed members of ahl al-hall wa-al-aqd, literally means "those who have the power to bind and unbind," a kind of supreme body of organization that resembles the advisory council. MMI has a paramilitary wing as well named Laskar Mujahidin (Mujahidin Paramilitary), which has trained its members in guerrilla technique and sent them for a jihad in the Moluccas in 2000. The most likely place to train the fighters is Hudaibiyah camp in Mindanao, where they are given instruction on using weapons and bombs. A few hundred of their members possibly gained a combat experience in Afghanistan and many more are likely to have fought in the southern Philippines (Bruinessen, 2002: 7).

According to the radicals, JI should remain underground until the time was ripe to move toward an Islamic state. Sungkar has frequently said that the struggle of Indonesian Muslim is comparable to that of the Prophet in Mecca, who had adopted a strategy of working in secret. Therefore, any attempt to struggle openly for an Islamic state of Indonesia was likely to be crushed by the enemies of Islam (Jones, 2005a: 3). They retorted that the political system might more open, but it was still controlled by secular government, and it is dangerous for a clandestine organization to exist side by side with an open one, particularly with an overlapping mem-bership. The radicals argued that any accommodation with a non-Islamic political system could contaminate the faithful members of JI ( Jones, 2004: 3).

The rift among JI members was also reflected in their disagreement over when, where and how to wage jihad. A key fault line was between those associated with Hambali, a leader of Mantiqi I, including most of the people involved in the Bali and JW Marriott bombings, who have been 
influenced by al-Qaedas 1998 fatwa urging attacks on western targets, and Abu Fatih, a leader of Mantiqi II, who sees the fatwas implementation as inappropriate for Indonesia and jeopardizing the longer-term strategy of creating an Islamic state through education and religious outreach. Abu Fatih also questioned whether there was a clear enemy to fight in Indonesia, which was very different from Afghanistan, for example, where Muslims had clearly been attacked by the Soviet Union. This stance was also shared by Salamat Hashim, a leader of MILF (Jones, 2004: 3). The issue of the religious and tactical merit of pursuing violent jihad remains a primary source of tension within JI organization. Sidney Jones says that JI is frag-menting, with factions conducting their own operations with little or no reference to the central leadership (Jones, 2003: 31).

\section{Conclusion}

The influence of the DI movement on JI is unmistakable and shows us that contemporary Middle Eastern influences are not required to create a violent jihadist movement in Indonesia. Such influences may be a sufficient but not a necessary condition for the rise of extremism. Local factors, such as socio-economic marginalization and political alienation also play a powerful role. Thus it is misleading to see JI as purely, or even predominantly, a product of external and particularly Middle Eastern influences. JI is more accurately characterized as a hybrid of local and international forces. It has been molded by the deep and bitter historical experience of radical Muslims in Indonesia, overlaid with global jihadist tendencies. It has distinctive local quality. It is a hallmark of al-Qaeda that it is able to inspire organizations such as JI and draw them into its network, while also allowing those groups to pursue their more parochial agendas.

In my opinion, JIs concept of a South-East Asian super-state, forming part of a global Islamic caliphate, is flawed. The overwhelming majority of the population of Indonesia, and of South-East Asia more broadly, appears to reject JIs vision and its-use of violence to further its aims. The region has seen how JI is prepared to damage regional economics in pursuit of its own ideological goals. Nation-states and nationalism are also major hurdles. JIs ultimate aim of uniting South-East under one Islamic leadership denies 
the widely acceptable modern political systems of the regions. The regions have adopted nation-states as the viable political systems governing the life of their citizens; changing it into Islamic caliphate of South-East Asia will create huge disruption, a-consequence that will be avoided by the government of the regions. Moreover, different historical roots.and distinct agendas of its potential allies in South-East Asia effectively hamper the idea of creating a unified South-East Asian Islamic state. JI relies on operational cooperation with other radical organizations in the region, based on shared values and ties forged overseas or while waging militant jihad in inter-communal conflicts in the regions. However, JI does not command the obedience of these other organizations. Even within JI there is division over how and where to wage jihad and differences over the appropriateness of targeting civilians.

\section{Postscript}

Before the Bali bombing on October 12, 2002, I was not aware of the existence of JI in Indonesia. I thought that JI is only a scapegoat created by CIA to press Indonesian government tojoin the American global campaign against terrorism. Until Bali attack, Indonesian government officials acknowledged JIs presence elsewhere, but denied its existence in Indonesia. The Government attributed the attack to al-Qaeda, not JI, hoping to place the blame on foreigners, not Indonesian themselves. Even our previous vice president, Hamzah Haz, demanded the media not to make hasty connection between the Bali attack and his friend, Abu Bakar Baasyir. However, the investigation over the bombing led to the arrest of over thirty suspects, many of whom had very strong links with Baasyir. It is true that during the investigation, all the suspects denied their link with Baasyir, let alone acknowledged him to be the leader of JI. However the former leader of Mantiqi III, Nasir Abas, mentioned in his book that for the sake of the organization security, once they got caught, JI members would deny their membership in this clandestine organization. Baasyir might not involve directly in the bombings, and the perpetrators acted on their owninitiatives. However, if he is proven to be an Amir of JI, however weak his leadership might be, there is no reason to let him free. Under the pressure from Ameri- 
can government and its neighbors, especially Australia, Indonesian government announced that it would carry out an investigation on Baasyir, but it would not arrest him just because foreign governments have suspicions of him. The government is also under considerable popular and political pressure to withstand the influence of foreign governments. Reading from various sources has given me a strong belief that the radical Muslim groups have deeply involved in many violent actions throughout Indonesia. It is not surprising for me if they resort to violent actions, since the idea of violent jihad is not new to Indonesian Muslims. The religious nuanced conflicts in Moluccas and Poso, and the current situation in some parts of Muslim world only heightened the motive to wage violent jihad against those who were portrayed as Muslim enemies.

In regard to the measures and actions taken by governments in South East Asia to combat JI and to reduce the vulnerability of the region to JI violent activities, it has been widely covered by the media that the Indonesian police have tracked down those responsible for the Bali and JW Marriott-bombings, and arrested over 100 suspected JI members since Bali Bombings. Malaysia has also detained more than 100 suspected militants under its Internal Security Act and established South-East Asian Regional Center for Counter-Terrorism (SEARCCT), which focuses on regional training and counter-terrorism capacity-building. The Philippines has arrested a number of key members of suspected JI, announced "14 Pillars of Policy and Action" to combat international terrorism and implemented UN Security Council Resolution 1368. Singapore has continued its vigorous campaign against JI, since its discovery in December 2001 of JI plots to target Westerners. It has also issued Restriction Orders against 30 people because of their links to JI and MILF. In 2003 Thailand authorities have arrested top JI leader, Hambali. This arrest was considered a significant breakthrough in the regional campaign against terrorism.

\section{References}

Abas, Nasir. 2003. Membongkar Jamaah Islamiyah. Pengakuan Mantan Anggota JI. Jakarta: Grafindo Khazanah Ilmu. 
Abuza, Zachary. 2003. Militant Islam in Southeast Asia, Crucible of Terror. London: Lynne Rienner Publishers.

Ayubi, Nazih. 1991. Political Islam: Religion and Politics in the Arab World. London: Routledge.

Bruinessen, Martin van. 2002. "The Violent Fringes of Indonesias Islam," in ISIM Newsletter 11, 7.

Dijk, Cornelis van. 1981. Rebellion under the Banner of Islam: The Darul Islam in Indonesia. The Hague: Martinus Nijhoff.

Gunaratna, Rohan. 2002. Inside al-Qaeda. Global Network of Terror. New York: Berkeley Books.

Jones, Sidney. 2002. Al-Qaeda in Southeast Asia: The case of the "Ngruki Network" in Indonesia. Jakarta/Brussels: International Crisis Group.

. 2003. Jemaah Islamiyah in South East Asia: Damaged but Still Dangerous. Asia Report No. 63. Jakarta/Brussels: International Crisis Group.

.2004. Indonesia Backgrounder: Jihad in Central Sulawesi. Asia Report No. 74. Jakarta/Brussels: International Crisis Group.

. 2005a. Indonesia Backgrounder: How Jemaah Islamiyah Terrorist Network Operates. Asia Report No. 43. Jakarta/Brussels: International Crisis Group.

. 2005b. Recycling Militants in Indonesia: Darul Islam and the Australian Embassy Bombing. Asia Report No. 92. Jakarta/ Brussels: International Crisis Group. 